FRANZ LISZT 


\section{FRANZ LISZT}

MUSICIAN, CELEBRITY, SUPERSTAR

\section{OLIVER HILMES}

TRANSLATED BY STEWART SPENCER 
First published in English by Yale University Press in 2016

English language translation copyright (c) 2016 Stewart Spencer

Originally published under the title Liszt Biographie eines Superstars by Oliver Hilmes (c) 2011 by Siedler Verlag, a division of Verlagsgruppe Random House GmbH, Munich

All rights reserved. This book may not be reproduced in whole or in part, in any form (beyond that copying permitted by Sections 107 and 108 of the U.S. Copyright Law and except by reviewers for the public press) without written permission from the publishers.

For information about this and other Yale University Press publications, please contact:

U.S. Office: sales.press@yale.edu yalebooks.com

Europe Office: sales@yaleup.co.uk yalebooks.co.uk

Set in Minion Pro by IDSUK (DataConnection) Ltd

Printed in Great Britain by TJ International Ltd, Padstow, Cornwall

Library of Congress Cataloging-in-Publication Data

Franz Liszt : biography of a superstar / Oliver Hilmes ; translation, Stewart Spencer.

Franz Liszt. English

New Haven : Yale University Press, [2016] | "Originally published under the title Liszt: Biographie eines Superstars by Oliver Hilmes " 2011 By Siedler Verlag, a division of Verlagsgruppe Random House $\mathrm{GmbH}$, Munich.” | Includes bibliographical references and index.

LCCN 2015034552 | ISBN 9780300182934 (c1 : alk. paper)

LCSH: Liszt, Franz, 1811-1886. | Composers-Biography. | Biographies. lcgft

LCC ML410.L7 H5513 2016 | DDC 780.92-dc23

LC record available at http://lccn.loc.gov/2015034552

A catalogue record for this book is available from the British Library.

10987654321 